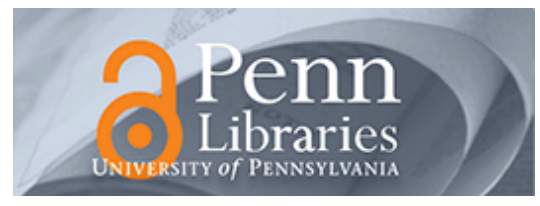

University of Pennsylvania ScholarlyCommons

\title{
Ask a Feminist: A Conversation with Cathy J. Cohen on Black Lives Matter, Feminism, and Contemporary Activism
}

Cathy Cohen

University of Chicago

Sarah Jackson

University of Pennsylvania, sarah.jackson@asc.upenn.edu

Follow this and additional works at: https://repository.upenn.edu/asc_papers

Part of the Communication Commons

\section{Recommended Citation}

Cohen, C., \& Jackson, S. (2016). Ask a Feminist: A Conversation with Cathy J. Cohen on Black Lives Matter, Feminism, and Contemporary Activism. Signs: Journal of Women in Culture and Society, 41 (4), 775-792. https://doi.org/10.1086/685115

At the time of publication, author Sarah Jackson was affiliated with Northeastern University. Currently, she is a faculty member at the Annenberg School of Communication at the University of Pennsylvania.

This paper is posted at ScholarlyCommons. https://repository.upenn.edu/asc_papers/772

For more information, please contact repository@pobox.upenn.edu. 


\title{
Ask a Feminist: A Conversation with Cathy J. Cohen on Black Lives Matter, Feminism, and Contemporary Activism
}

\author{
Abstract \\ Herein, Sarah J. Jackson interviews Cathy J. Cohen on the potentials for feminist theory in racial justice \\ movements. Topics addressed include the barriers and bridges between activists and academics, the \\ unique ways in which race and gender intersect in state violence, challenges for feminist academics of \\ color engaged in activism, and the shape of the \#BlackLivesMatter movement. \\ Disciplines \\ Communication | Social and Behavioral Sciences

\section{Comments} \\ At the time of publication, author Sarah Jackson was affiliated with Northeastern University. Currently, she \\ is a faculty member at the Annenberg School of Communication at the University of Pennsylvania.
}




\section{Ask a Feminist: A Conversation with Cathy J. Cohen on Black Lives Matter, Feminism, and Contemporary Activism}

had the pleasure of having this conversation with Cathy J. Cohen, the David and Mary Winton Green Professor of Political Science and chair of political science at the University of Chicago, in late 2015. Cohen's work, both academically and as an activist, has inspired my own, particularly in terms of making connections between black feminist theory, social movements, and issues of race and racism in the United States. Cohen is the principal investigator of two major social change projects: the Black Youth Project (BYP100) and the Mobilization, Change and Political and Civic Engagement Project. Her books, Democracy Remixed: Black Youth and the Future of American Politics (2010) and The Boundaries of Blackness: AIDS and the Breakdown of Black Politics (1999), have offered important interventions in scholarship on race and politics. She is also the coeditor, with Kathleen B. Jones and Joan C. Tronto, of Women Transforming Politics: An Alternative Reader (1997).

Since the publication of my book, Black Celebrity, Racial Politics, and the Press: Framing Dissent (Jackson 2014), I have been particularly compelled by the use of technology by racial justice activists like the women who started \#BlackLivesMatter. My recent collaborative work with Brooke Foucault Welles, "Hijacking \#myNYPD: Social Media Dissent and Networked Counterpublics" (Jackson and Welles 2015) and "\#Ferguson Is Everywhere: Initiators in Emerging Counterpublic Networks" (Jackson and Welles 2016), has illustrated that everyday citizens_particularly young women and people of color-are having a very real impact on national narratives of equality and citizenship. In the following conversation, Cohen and I discuss the potentials for feminist theory in racial justice movements, the unique ways in which race and gender intersect in state violence, challenges for feminist academics of color engaged in activism, and the shape of the \#BlackLivesMatter movement. You can follow us on Twitter at@cathyjcohen and @sjjphd, respectively.

Sarah Jackson (SJ): I'd like to begin by asking what role you see feminism, and feminist scholarship in particular, playing in today's racial

[Signs: Journal of Women in Culture and Society 2016, vol. 41, no. 4]

(C) 2016 by The University of Chicago. All rights reserved. 0097-9740/2016/4104-0003\$10.00 
justice movements, as well as what you think scholars can learn from activists and vice versa.

Cathy Coben (CC): That's a really big and important question. At its most basic level I think that feminism at the very least-and maybe most importantly-makes us stop and ask about the role that women, and here I mean both cis and trans women, are playing at this particular time in the multiple movements that are emerging, and particularly, at least for the work that I'm doing and thinking about, in what people are calling the "black lives movement."

But I think that feminism does a number of different things in relation to racial justice movements today. I am especially thinking about the role of black feminism. I'll give you three things that I think it does: first, it makes us think differently about or, hopefully, expand where we look for victims and resisters to state violence. It says that while there's a traditional or normative model of who we think about as the victim of state violence, which is often a heterosexual man in a confrontation with police, we know that state oppression manifests not only in that model but in lots of different places. It happens through the denial of state welfare assistance, and it happens in the ways we militarize the public schools that primarily black, Latino, and poor kids attend. These are different forms of state violence. And I think feminism fundamentally makes us ask the question, when we confront the traditional model, what are the other examples of state violence or state oppression that we need to be paying attention to? Of course, feminism has us intervene in traditional sites of state violence by asking the very basic question about the status of women. So if we're looking at campaigns that are mobilizing against direct police violence and only mention men as targets, feminism would have us ask, where are the women? The Say Her Name campaign (AAPF 2015), the work that the BYPl00 is doing in Chicago around the Rekia Boyd case (BYPl00 2015), and, some would argue, even the Sandra Bland case (Alter 2015) are examples of attention to direct police violence where we can say, "Well, wait a minute, this is also happening to women."

SJ: And there was just the Charnesia Corley case in Texas, where the police did a vaginal search during her traffic stop (Lohr 2015).

CC: Yes, and we can go down the list of incidents that people will recognize as police violence. But again I think what feminism says is 
that we have to expand how we understand state oppression and more specifically state violence. We have to not only be attentive to what are now recognizable forms of state violence but also move beyond the "traditional" models of state violence to mobilize for justice for broader communities of people.

Second, I think feminism is informing the movement for black lives in terms of how it's structured and its leadership. There's some important feminist work that tells us that there are different forms of leadership that we should be paying attention to. Whether it is Belinda Robnett's (1997) work on the civil rights movement and bridge leaders or the exceptional work that Barbara Ransby (2003) has done thinking about Ella Baker and more democratic forms of radical leadership, I think many of the young leaders in the Black Lives Matter movement recognize that the male charismatic leader, or the singular charismatic leader, is not the form of leadership that they adhere to or they are going to put forth. In fact, many of these new organizations are led by young black women who identify as queer and who promote the idea, as Barbara Ransby has noted, that far from this movement being led by one person or having no leaders, it is a leaderful movement with cis and trans women taking positions of power. So the organizations that are part of a network of groups working under the broad framework of the Black Lives Matter movement look different and structure their leadership differently than organizations significant to the civil rights movement in part because of feminist teaching, feminist scholarship, especially black feminist teaching and scholarship, and the fact that many of these young activists have been in the classroom learning about these alternative forms of organizing and leadership.

Third, I think that feminism should also require us to think broadly and radically about what we are fighting for-the outcomes we seek to the oppression that we face. Radical black feminists, in particular, have argued that while immediate policy changes can be part of what we fight for, the structural transformation of the lived condition of marginal communities has to guide our struggle. For example, if you take the work of someone like Beth Richie (2012), who is an exceptional black feminist scholar focused on issues of incarceration and violence against women, she has written that when most think about violence against women, the traditional response in the mainstream domestic violence movement has been to involve the state, specifically passing laws against domestic violence and involving the police. But this response doesn't take into account the fact that the state is 
the oppressor in many communities of color and poor communities. So involving the state or turning to police intervention cannot be the place we land when building a movement to address the structural conditions that foster or contribute to violence against women. Similarly, feminist organizations like INCITE! and the BYP100 have argued that working against the prison industrial complex must be focused on improving and transforming the conditions under which incarcerated folk exist, but we must also question the existence of prisons and seriously contemplate a broader structural approach that promotes a prison abolition agenda. ${ }^{1}$ The point is that feminism should turn our attention to structure, not just as a limiting factor but also as a jumping off point as we imagine a broader liberation agenda.

SJ: Yes, absolutely. I think all of those points needed to be made. And something that you just said made me think about how, as a black woman scholar, I have been very interested to see how the contemporary movement is redefining what questions are being asked, who's in leadership, etc. It's also been interesting to see what role academics think they should or shouldn't play in the movement versus what role activists think academics should and shouldn't play. These expectations sometimes seem to butt heads, but there is also a space for academics who are activists, and many of us-particularly those of us who are women of color-are already deeply engaged in the activism we're studying. The academy as The Academy is, like any other American institution, often an oppressive force and contradictory in nature to antiracist and feminist activism, but those of us within the academy who as individuals subscribe to antiracist and feminist politics can have authentic ties to activism. So I wonder if you could say a little bit about what possibilities and roles you see for academics in relation to these movements.

CC: This is a hard one. I can think of at least four or five examples of organizations that have either been started by academics or are deeply in conversation with academics that are helping to fuel the Black Lives Matter movement. For instance I could talk about the BYP100, which grew out of the Black Youth Project, which I head. We held a convening of one hundred young black activists on the same weekend in which the George Zimmerman verdict was announced. Out of

\footnotetext{
${ }^{1}$ See INCITE! (2006) and http://www.incite-national.org/.
} 
disgust with the verdict and as a result of the skills that these organizers and activists have, they created this new organization called the BYP100, which has really taken off and is doing incredible work (BYP100 2013). And I've been honored to be in conversation with the leadership of that organization. We are getting ready to do a special issue with the journal Souls that will focus on black youth activism and will include both academics and activists. This is one model of an activist academic supporting the work of activists rooted outside the academy.

You could also look at Salamishah Tillet's work with A Long Walk Home; you could look at Barbara Ransby's work with the Social Justice Initiative and Ella's Daughters; you could look at academics like Angela Davis or Beth Richie, who are both involved in INCITE!, or Kimberlé Crenshaw's work with the African American Policy Forum and the Say Her Name campaign. ${ }^{2}$ We can go down a very long list of feminist academics doing work with the Black Lives Matter movement organizations or doing their own political workand I apologize to people I didn't include. I would argue that the black feminists I just named and many more have been engaged in activism as much as they have been engaged in the academy. Particularly for women of color, there is an understanding that you may never be fully embraced in the academy, and what this understanding does is give you a kind of freedom to pursue the work that will transform institutions of oppression, including the academy. So I think women of color have always endured a kind of love-hate relationship with the academy, with our positioning allowing us to be insiders-outsiders. At our best moments this insider-outsider status has allowed us to be deeply engaged and accountable to communities outside the academy: the communities from which we come, the communities that we call home, and the communities that many of us study and promote. So it's not surprising, I would argue, in particular for women of color and feminists of color, that this idea of bridging what we do inside the academy and outside the academy is almost second nature-that's what we have always done. And for most of our careers this duel status has been the thing that people have often used to dismiss our work. Now, with the emergence of liberation movements in communities of color, people who are not politically engaged in the same way are excited by it. But, sadly, I be-

\footnotetext{
${ }^{2}$ See http://www.alongwalkhome.org/; http://www.uic.edu/depts/oaa/sji/; http:// ellasdaughters.blogspot.com/; http://www.incite-national.org/; http://www.aapf.org/.
} 
lieve this too will pass and there will be another generation of young people, young scholars, young feminists, doing political work in and outside the academy who will again be discredited for doing such work but who will understand that their calling is not only about getting tenure but also leveraging the privilege and resources that can come with a life in the academy to resist and transform oppressive institutions that too often include the academy.

SJ: Thank you so much. Honestly that was a very self-indulgent question because this is something that I think a lot about, personally.

CC: Can I say one more thing? Something else that interests me about this moment and the intersection of the academy and organizing outside the academy - and I've said this in other venues - is that we're seeing the emergence of a leadership that has often been in our classrooms. Many of the young leaders that I've interacted with have been in African American studies classes, have been in ethnic studies classes, have been in feminist, gender, and women's studies classesthese might even be their majors. So our entry into the academy may not have transformed that institution, but it has informed the thinking of a generation of young people who are now leading these movements, and I think it's being manifested in decisions about how they structure their organizations, or what leadership looks like to them, and who they understand to be members of their communities-for example, they are conceiving of the black community in ways that are perhaps much more expansive than what we've seen before. I think that's another way in which the academy and activism are productively intersecting.

SJ: That's so true. Speaking of the leadership, we know that the hash-tag \#BlackLivesMatter was created by queer black women (Garza 2014), which probably can't be said enough, and in some media outlets there's been a lot of buzz and there have been several major newspapers or online magazines that have written pieces about the new civil rights movement (Demby 2014; Eligon 2015) and the new face of racial justice activism. They have suggested that the inclusion of queer folks and women, or queer women, is maybe a new thing. But we know that these folks have been central to activist movements all along-we know who threw the first rock at Stonewall-and we know that this is part of the story that has actually been erased (see Adsit 2015). This may be something that we both know 
the answer to, but do you think that the inclusivity of this moment is new? You have suggested just now that in some ways it may be, but perhaps in some ways it isn't. So I'd like you to talk a little bit about that, and also discuss how intersectional politics in particular might be evidenced in today's movement and how this is similar to or different from a previous moment.

CC: You've got a lot packed into these questions! On the question of whether it's new: not completely, but partly. There have always been radical black women or radical women engaged in mobilization, organizing, and leadership: we know that is not new. We can read the books on Fannie Lou Hamer (Mills 1994); we can read the books on Ella Baker; we can read books by Elaine Brown (2015) (although I'm not sure you can call her a radical, but . . .); we can read Anna Julia Cooper. We can go through that individualized history to say that women have been a part of the leadership; they've been a part of the strategizing. And I would argue that trans women have also had a long history of organizing and resistance that far too often is not held up, ranging from the Compton's Cafeteria Riot, to Stonewall, to the mobilization around $\mathrm{CeCe} \mathrm{McD}$ onald and beyond. So we know that the women, women of color and queer folk, have always been central to our struggles. That part is not new. I think it's new information for some people, but if you think about the history and know the history, it's not new.

I do think what's new is the ways in which, at this moment in the Black Lives Matter movement, young, black, often queer women are not just doing the work but are part of a collective leadership. The fact that they are visible and vocal, not just in one organization but across a number of organizations, shaping the direction of this movement-this is something that's new. And they are leading not specifically women's organizations but also what many of us recognize as black liberation organizations. While the inclusion and in some cases leadership of women, queer, and LGBT folks in our movements is not new, these individuals, like Bayard Rustin, haven't always had the opportunity to be a visible or foregrounded part of the black struggle, so in that sense I think that it's new.

Another thing that's new at this moment is the recognition and articulation of a kind of black queer nationalist politics that is informing the politics of many organizations involved in the black lives movement. I should say that when I say "black lives movement," I'm talking about the multiple organizations that are en- 
gaged in the national or international mobilization that is commonly known as Black Lives Matter, not just the one organization of the same name. To assert the significance of queer bodies as part of the black community is new and important. That is a struggle that has existed for some time and really took root when black activists were responding to HIV and AIDS in black communities (see Cohen 1999), where we were trying to say that there were lesbian and gay and bisexual and trans folks who were part of our communities and their issues, in this case their struggle against HIV/AIDS, had to be addressed by both national organizations and the state but also by indigenous black organizations. Now activists are saying that not only are gay, lesbian, trans, and queer folk part of our communities, but they are part of the leadership, and they-for example, cis and trans women-have to be at the center of how we think about black liberation. The centering of cis and trans women and lesbians and gay men as members and leaders of our communities - that to me is significant and new. It is an expansion of our understanding of black communities that I don't think we have seen articulated in the past. The way in which people are also pushing back by using a queer lens to challenge the static nature of categories and identities is also important. This perspective is not always articulated or productively struggled with, but I do think there's the possibility for these organizations to borrow from a queer lens, we might say, and to think about the ways in which different bodies are marginalized and made to be queer in the eyes of the state as well as in their own communities. This idea of queering marginalized bodies, in particular those of color, was an argument I tried to articulate in my article "Punks, Bulldaggers, and Welfare Queens" (Cohen 1997). This lens allows for and promotes different types of allegiances, not only racialized allegiances but also allegiances based on the positionality of people relative to the state, which queers us all or produces a bond of unity needed for the type of mobilization that we're beginning to see. For me, that is what's new and significant about the forms of leadership and organizational structures that we're seeing in this moment.

The other new development we could talk about is the constant articulation of the intersectional nature of both the oppression that people feel and the type of liberation and resistance that they want to mount; even though the framework for the moment is appropriately focused on police violence, people also understand the ways in which race and class and gender intersect. If we look at a campaign like Fight for \$15, which is about securing a living wage-often for 
women of color, who find themselves doing more work for less money - that's a kind of intersectional approach to understanding the significance and uniqueness of the positionality of black women while also saying that their positionality can speak to the condition of black people more generally. ${ }^{3}$ I don't think we have often seen movements say that the common thread of blackness is not just the male body, or the presumed cis male body, but in fact that cis and trans black women can represent the intersectional positionality and oppression that black communities face.

And finally, I think we're in a technological context that allows people who have traditionally been silenced or made invisible to have a voice or at least to have their voices and issues amplified. When we think about how the Black Lives Matter movement started with a hashtag, I wouldn't want to discount the significance of technology as an important tool for organizing today. I would not say that technology is a driving force, but it has been a critical tool in terms of democratizing the voices who can be a part of this movement.

SJ: That's actually a really good bridge to my next question. You already mentioned Sandra Bland, and it seems to me that the Bland case was the first time in recent memory that the mainstream media, not just the black media or the alternative media, actually covered an instance of state violence against a black woman as a major news story. It seemed to be a tipping point, in that this case was pushed into visibility by the current moment, and it suddenly became possible to realize, “Oh, it's not just black men!" Now of course Bland in particular was a middle-class cis black woman, so in many ways she was also an "easier" victim in terms of the media's framework, but I wonder if you could talk a little bit about the fact that we know that there are countless incidences of violence against trans women of color, against immigrant women of color, against cis black women, that we don't see. Could you talk about whether you think we are at a tipping point in the visibility of these other types of stories? Or what other work might need to be done to fully integrate those conversations?

CC: That's a great question. I don't think I have a great answer. This feels confusing to me in the sense that, even given all the things you said, there are reasons why we might expect that the Bland case

\footnotetext{
${ }^{3}$ See http://fightfor15.org/.
} 
would resonate. One has to do with what we were talking about before: I think we now have a generation of new leaders, especially among the Black Lives Matter network, who are going to say that in fact the deaths of black women matter and who are going to try to hold up names and the experiences of cis and trans black women, trying to make other organizations and even the mainstream media pay attention to their lives. Today we have that kind of pushing and the organizational capacity to try to make that case. Of course, I think the role of digital media is also important here. There's a way in which, using the tools of new media, activists can circumvent what might be thought to be the mainstream or dominant press and try to build the story themselves, using platforms such as their organization's website, Twitter, YouTube, and Facebook.

I think Bland's case also resonated nationally because it seemed so extreme. While the country may be prepared to accept the killing of black men and marginalized black women at the hands of the state, the idea that someone like Sandra Bland would end up dead in police custody seemed extreme and unthinkable to many in this country. Bland, while a black woman, was also a middle-class, collegeeducated, light-skinned black woman who was engaged in an act that was not deemed violent. In fact, she was doing something that everyone has done, which is changing lanes without signaling. So everybody can say, "Damn, I've done that." So I think it was the perceived extreme nature of the case, the insignificance of the infraction (and I don't even know if changing lanes qualifies as an "infraction"), the way the officer's outrageous behavior escalates, the fact that Bland was in town to accept a job (thus fulfilling the American norm of self-dependence), the ability to see so much of the interaction unfold on video, and the capacity of organizations to push and to organize around the story with a leadership that understood how important it was to bring attention to the police violence black women face, all of this results in the Sandra Bland death becoming a national story. I think it's one of those moments where many factors came together.

But I'm not sure I'm prepared to say that the Bland case, as important as it was, marks a tipping point. When I see the same type of mobilization nationally around the Rekia Boyd case or the Marlene Pinnock case or the Dajerria Becton case that we have rightfully seen around the cases of Trayvon Martin, Michael Brown, and Eric Garner, then I'll say we have reached a tipping point. I'm not sure if it was this confluence of characteristics that allowed people to pay attention 
to the Bland case specifically or if it's a longer trend, but I think the pieces are at least in place to help put forward more and more cases of women, trans and cis, who are the targets of state abuse, often police abuse. I just hope people will pay attention.

Finally, I also think there has been a form of training that has gone on over the past year. We have trained people to pay attention to cases of police abuse, which has helped with people's recognition of the Bland case. Sadly, now that people have seen so many cases of black people being killed by the police, it is a familiar story that is recognizable and people are able to say, "Oh, that happened again, and this time it was to a woman." They are able to process the Bland case because far too many cases prior to the Bland death trained the public to pay attention. I don't know if this training process helps your point about having reached a tipping point, but at least people are more likely to believe, listen to, and pay attention to these types of stories.

SJ: Thank you for that. Were you at the Movement for Black Lives Convening in Cleveland? ${ }^{4}$

CC: I was not, but I heard many reports about it.

SJ: Yes, so did I. At this convening, there was a moment in the middle of the meeting when a deliberate effort was made to reaffirm the value of the inclusion of black trans lives. I wonder if you could speak a bit about the significance of trans inclusivity in both contemporary black activist and other activist spaces, as well as in scholarly spaces and in the work that we're doing in feminist scholarship.

CC: I think that it's important for any movement concerned with the liberation in particular of black people to be thinking about those individuals who are most marginalized nationally and in our own communities. And those are often poor people, trans and cis women, as well as LGB folks. So while we have made some progress in having activists and scholars detail the role that racism, sexism, and class play in structuring and truncating the lives of all black people, we still have much work to do to explain and challenge how heterosexism and heteronormativity work to limit the lives of black people. Similarly, I think there's still a lot of work to be done in support of trans mem-

\footnotetext{
${ }^{4}$ See http://movementforblacklives.org/.
} 
bers of our community, acknowledging their struggles, vulnerability, and growing resistance.

It's important for those of us who profess to be concerned with the liberation of black people, who say we love black people, to include and make central to our work those most marginal in our communities because improving their lives should help move us all down the road toward liberation. In this case it means modeling trans inclusivity, making visible and central the struggles of trans folks in our analysis and movements. The hesitation to making trans struggles central to our work, at least among many black feminists of my generation, those who came to feminism when second-wave feminism was dominant (if we even want to adhere to that wave structure), is that some of the most visible or prominent trans spokespeople seem to affirm a strict, conservative, and essentialist gender binary. I think people often confuse the more public and visible articulations of some trans celebrities with a universal trans politics. I believe that we have to pay attention to the nuances in trans politics. Just as LGBT politics is different from queer politics and women's politics is different from feminist politics, we have to acknowledge that an essentialist trans politics is very different from a radical feminist trans politics. Thus, concern emerges when one hears the language of what seems like a call to biological essentialism-such as when Caitlyn Jenner says "I am a woman. . . . My brain is much more female than it is male." ${ }^{5}$ I think that essentialist propaganda drives me and my feminist friends crazy. But when we hear the informed and radical stories of trans folks who refuse to live on the binary or someone like Janet Mock (2014) who, while choosing a more traditional gender performance, talks incisively about the ways being a trans woman is related to the positionality of cis black women, who also are at the bottom of the racial order and gender hierarchy, the connection between the lives and struggles of black cis and trans women are made clear, highlighting the larger structures that we're both fighting against. A radical trans analysis makes clear that our struggle is not so that everyone can find their essentialist selves, but instead this movement is about breaking down systems of oppression based on gender and class and race and sexuality that limit the ability of people to have full and happy lives - from having good jobs, to having the kind of intimate partners that they want, to experi-

${ }^{5}$ Interview with Diane Sawyer, 20/20, ABC, April 24, 2015, http://abc.go.com/shows /2020/listing/2015-04/24-bruce-jenner-the-interview. 
encing joy, to having agency, to having control over their bodies and sexuality.

Getting us to that point probably means more dialogue, more struggle, as Bernice Johnson Reagon (1983) would say, more being uncomfortable around the coalition and intersection of work that we want to do. I sometimes worry that we've accepted a dialogue around trans politics that we haven't struggled with enough. I think there is a way that both in the academy and outside of the academy, we haven't figured out where the space is to really have this dialogue and come to an understanding around the kind of trans feminist politics that I think is radical and transformative and not primarily essentialist.

SJ: Would you say that that's the case both for feminists working within the academy and for activists outside of it?

$C C$ : That's a great question. I think there is a way that, yes, both in the academy and outside of the academy, we haven't figured out where the space is to really have this dialogue and come to an understanding around the kind of trans feminist politics that I think is radical and transformative and not primarily essentialist. Because of trans-exclusionary radical feminists, I think it's been hard to find a space where people feel like they can actually have that dialogue and move to a more informed position. I'm not sure that we've done enough, either in the academy or outside the academy, but we've probably done more in the academy, actually.

SJ: This is something that I'm also still thinking about. And I have been talking a lot about this recently because Suzanna Walters's (2014) book basically makes the same argument about the LGB folks who say, "I was born this way; it's in my genes," and how this is actually counter to a radical feminist liberatory theory that would say, “actually we shouldn't justify treating people like human beings by any sort of genetic or biological criteria." So I like how you distinguished that narrative that has arisen around trans identity as being an essential thing as opposed to a radical trans identity that is rooted in a more feminist liberatory ideology. It seems like a really good way to think about it.

CC: I'm still struggling to figure it out as well. To me it's the difference or the tension between a women's rights politics and a feminist 
politics, or an LGBT politics and a queer politics. What I'm looking for and have found, I hope, is a radical trans feminist politics that is thinking about and rooted in the transformation of institutions that would oppress and limit people's understanding and performance of gender. I am, thus, interested in a politic that is rooted in and investigates life in contrast to binaries and static categories. That's the kind of feminist trans politics that I'm committed to, and that's the inclusion I want in the Black Lives Matter movement. People may not like this, but without an intentional politics, I don't see trans as inherently radical. I think there are many instances where marginal individuals are inserted into traditional institutions or movements and they do something to change the dynamics but they don't necessarily change these spaces and entities in a radical way that is open and more equitable. I'm interested in trans feminist politics in the same way that I'm committed to a black feminist politics that is tied to a transformative liberatory agenda.

SJ: That makes perfect sense. There also has been a lot of talk about this idea that there's a generational divide among racial justice activists. The media can't seem to get enough of comparing contemporary activists to civil rights movement activists, which is problematic in and of itself because the contextual differences are endless, as well as because everyone's public memory of the civil rights movement has been so sanitized. But there is this idea that there is a generational divide, and I think we have seen this divide in some spaces. For example, there was that moment in 2014 when Al Sharpton got shouted down (see Demby 2014). People were saying, "We didn't ask you to be here to talk about this." Maybe I'm wrong about this, but I think in some ways these generational differences-I don't like the word "conflict" - are analogous to the waves of thought in feminism, and maybe this current moment of activism looks more like the fourth wave of feminist thought. Or maybe it doesn't? I wonder if you have any thoughts about that.

CC: Here's the problem for me with the generational framework, and I guess we could say it mirrors my concerns about the wave framework that other people have already articulated: when you start com-paring waves or generations, you homogenize those waves and gen-erations. So I shudder when I hear you say Sharpton might speak for my generation. I'm like, “Oh my God, no! That's just scary!” I think that's what happens when we start to say that there are certain indi- 
viduals that represent a generation. One major problem with that approach is that the political/ideological tensions between individuals within the generation are made invisible. As I see it, if there is any divide, it's more an ideological one: it is the divide between those who understand themselves to be feminist and who insist that cis and trans women are just as important to our conversation and movement as cis men versus those that don't share this understanding. To me, that's the divide. It's a divide that's built around, as we talked about earlier, our larger vision of black liberation and who is a central part of black communities; it's a divide between the structure of more traditional civil rights organizations and the organizations mobilizing today; it's a divide between those who support new models of collective leadership in our protest organizations versus those who want one charismatic leader to point to. That, I think, is the divide, and this speaks to Sharpton also. He comes out of a tradition, an ideological positioning, that would lead him to seek the role of the male charismatic leader and believe that there should be one person and one organization leading the way. I think the divide is less about generation, even though I think that's the easiest place for people to point, but I think if you dig a little deeper, beyond generation, you will see different political and ideological commitments driving the differences in the approach to social movements or in opinions about the Black Lives Matter movement. To me, this divide maps onto the issue of the waves model in feminist studies because, as you know, black feminists have contested the wave theory and questioned when waves start and end and who gets included. In the waves model you see the flattening of differences and dissension within waves as a way to bring into stark contrast those differences that exist between waves.

SJ: It's interesting because now that you say that, I think it does map: it seems like the divide within racial justice activism around what leaders look like and whose story should be included maps more onto the conflicts - both inside and outside of academia-between upper- or middle-class white feminists and feminists of color and working-class feminists, who have always had this ideological head butting, where feminists of color, for example, have been saying, "Your feminism isn't necessarily inclusive; you're helping prop up the carceral state, and so on." And that's interesting because it's less about generations and more about where one's standpoint is coming from in the first place. That's a really interesting way to look at it. 
CC: But - to go back to the topic of trans inclusivity-I think another interesting aspect is that many of the trans women that we are talking about often come from poor backgrounds rather than middle-class backgrounds. They've been in completely vulnerable positions in terms of their lived experience. To me, that's a different positioning than a middle-class cis black feminist, so I think the question is, are we prepared to look at all of these differences in standpoint, as Patricia Hill Collins might talk about, and say that they're all significant? The divide that we saw, for example, in second-wave feminism, between black feminists or feminists of color, Latina feminists, Native feminists, and white feminists - that's an important one. But we know that we've complicated that account and that many people in the academy are in the academy because they have access to resources and some form of class mobility. So while folks of color can challenge and open up new possibilities in terms of thinking about feminism, we also want to pay attention to the class positioning of those women of color who are speaking in the academy, often to the exclusion of poor women or trans women, who often have a very different positionality with regard to both feminism and their lived dayto-day experiences.

Department of Political Science

University of Chicago (Cohen)

Department of Communication Studies

Women's, Gender, and Sexuality Studies Program

Northeastern University (Jackson)

\section{References}

AAPF (African American Policy Forum). 2015. "\#SayHerName: Resisting Police Brutality against Black Women.” Report, July 16. http://www.aapf.org /sayhernamereport/.

Adsit, Lexi. 2015. "Stonewall Is in Our Blood: How the New Film's White Gay Hero Is the Latest Effort to Erase Trans Activists of Color." Salon, August 10. http://www.salon.com/2015/08/10/stonewall_is_in_our_blood_how_the _new_films_white_gay_hero_is_the_latest_effort_to_erase_trans_activists_of _color/.

Alter, Charlotte. 2015. "Sandra Bland's Not the First Woman to Experience Police Violence." Salon, July 22. http://time.com/3965032/sandra-bland-arrest -video-police-violence/.

Brown, Elaine. 2015. A Taste of Power: A Black Woman's Story. New York: Anchor. 
BYP100 (Black Youth Project 100). 2013. “\#BYP100 Responds to George Zimmerman Verdict." YouTube video, July 15. https://www.youtube.com/watch ?V=DUxKJXK5WAc.

. 2015. "National Day of Action for Black Women and Girls: \#Justicefor Rekia \#SayHerName \#BlackWomenMatter.” Black Youth Project 100, May 20. http://bypl00.org/justice-for-rekia/.

Cohen, Cathy J. 1997. "Punks, Bulldaggers, and Welfare Queens: The Radical Potential of Queer Politics?” GLQ 3(4):437-65.

- 1999. The Boundaries of Blackness: AIDS and the Breakdown of Black Politics. Chicago: University of Chicago Press.

- 2010. Democracy Remixed: Black Youth and the Future of American Politics. Oxford: Oxford University Press.

Cohen, Cathy J., Kathleen B. Jones, and Joan C. Tronto, eds. 1997. Women Transforming Politics: An Alternative Reader. New York: New York University Press.

Demby, Gene. 2014. "The Birth of a New Civil Rights Movement." Politico, December 31. http://www.politico.com/magazine/story/2014/12/ferguson -new-civil-rights-movement-113906.

Eligon, John. 2015. "One Slogan, Many Methods: Black Lives Matter Enters Politics." New York Times, November 18. http://www.nytimes.com/2015/11 /19/us/one-slogan-many-methods-black-lives-matter-enters-politics.html ?smprod=nytcore-iphone\&smid=nytcore-iphone-share\&_r=l.

Garza, Alicia. 2014. "A Herstory of the \#BlackLivesMatter Movement.” Feminist Wire, October 7. http://www.thefeministwire.com/2014/10/blacklivesmatter $-2 /$.

INCITE! Women of Color against Violence. 2006. Color of Violence: The Incite! Anthology. Cambridge, MA: South End.

Jackson, Sarah J. 2014. Black Celebrity, Racial Politics, and the Press: Framing Dissent. New York: Routledge.

Jackson, Sarah J., and Brooke Foucault Welles. 2015. "Hijacking \#myNYPD: Social Media Dissent and Networked Counterpublics." Journal of Communication. http://onlinelibrary.wiley.com/doi/10.1111/jcom.12185/pdf.

—. 2016. "\#Ferguson Is Everywhere: Initiators in Emerging Counterpublic Networks." Information, Communication and Societv 19(3):397-418.

Lohr, David. 2015. "Woman Says Gas Station Strip Search Was Like Sexual Assault." Huffington Post, August 10. http://www.huffingtonpost.com/entry /texas-strip-search-public_55c8f940e4b0923cl2bdb903.

Mills, Kay. 1994. This Little Light of Mine: The Life of Fannie Lou Hamer. Lexington: University Press of Kentucky.

Mock, Janet. 2014. Redefining Realness: My Path to Womanhood, Identity, Love and So Much More. New York: Atria Paperback.

Ransby, Barbara. 2003. Ella Baker and the Black Freedom Movement: A Radical Democratic Vision. Chapel Hill: University of North Carolina Press. 
Reagon, Bernice Johnson. 1983. "Coalition Politics: Turning the Century." In Home Girls: A Black Feminist Anthology, ed. Barbara Smith, 356-68. New York: Kitchen Table.

Richie, Beth. 2012. Arrested Justice: Black Women, Violence, and America's Prison Nation. New York: New York University Press.

Robnett, Belinda. 1997. How Long? How Long? African-American Women in the Struggle for Civil Rights. New York: Oxford University Press.

Walters, Suzanna Danuta. 2014. The Tolerance Trap: How God, Genes, and Good Intentions Are Sabotaging Gay Equality. New York: New York University Press. 